RESEARCH ARTICLE

\title{
Influence of Seedling Age and Planting Pattern on Yield, Labour Productivity and Economics of Transplanted Finger Millet
}

\author{
Tamilmozhi $\mathbf{R}^{\mathbf{1}}$, Karthikeyan $\mathbf{R}^{\mathbf{1}}$, Sakthivel $\mathbf{N}^{\mathbf{1}}$ and Ravichandran $\mathbf{V}^{\mathbf{2}}$ \\ 1* Department of Agronomy, Tamil Nadu Agricultural University, Coimbatore - 641003 \\ ${ }^{2}$ Department of Crop physiology, Tamil Nadu Agricultural University, Coimbatore - 641003
}

\begin{abstract}
The present study was aimed to evaluate the influence of seedling age and planting pattern on grain and straw yield, labour productivity, and economics of transplanted finger millet (Eleusine coracana L. Gaertn.) by conducting the field experiment at Tamil Nadu Agricultural University, Coimbatore during Kharif, 2019 (July to November). The experiment was laid out in split-plot design and each treatment was replicated thrice. It consisted of three seedling ages viz., 14, 17, and 20 days (old seedlings) as main plot factor and four planting patterns viz., rectangular $(30 \mathrm{~cm} \times 10 \mathrm{~cm})$ and square $(25 \mathrm{~cm} \times 25 \mathrm{~cm})$ planting with one and two number of seedlings per hill as subplot factor. From the experimental results, yield, labour productivity, and economics of finger millet differed due to seedling age and planting pattern. Transplanting of 20 days old seedlings under rectangular planting $(30 \mathrm{~cm} \times 10 \mathrm{~cm})$ with two seedlings per hill recorded higher grain yield, straw yield, labour productivity, gross return, net return, and B:C ratio. Younger seedlings of 14 days old transplanted under rectangular planting $(30 \mathrm{~cm} \times 10 \mathrm{~cm})$ with two seedlings per hill recorded a higher cost of cultivation.
\end{abstract}

Keywords: Finger millet; Labour productivity; Ecomomics; Seedling age; Planting pattern

\section{INTRODUCTION}

Finger millet is a predominant dryland crop due to its resilience and ability to withstand aberrant weather conditions and is majorly cultivated in the semiarid regions of Africa and Asia. The crop is well adapted to very poor and marginal uplands, where other crops cannot be grown successfully (AICSMIP, 2014). In India, finger millet is the third most crucial millet crop next to sorghum and pearl millet and accounts for nearly 60 percent of the global finger millet production. The area under finger millet cultivation in India was 1.19 million hectares with an average productivity of $1661 \mathrm{~kg} \mathrm{ha}^{-1}$ during 2017 (Chamoli et al., 2018). Nutritionally, finger millet is comparable with rice in terms of carbohydrate, protein, and fat and has 8 to 10 times more calcium than rice (Chappalwar et al., 2013). With several advantages, finger millet is considered as a crop for the future, which secures food and nutrition for growing populations.

Besides its adaptability and nutritious quality, the crop has the highest productivity among the millets. However, the results of past decades revealed that productivity was in a declining trend due to the cultivation of major food and commercial

*Corresponding author's e-mail: tamilaagri222@gmail.com crops. To utilize its benefits, research should be done to increase productivity without increasing the cultivated area. Among the several crop management strategies, altering the agronomic practices could increase productivity and profitability. Considering the several agronomic practices, transplanting is a prime factor that tends to improve the yield by ensuring optimum crop stand in the main field (Hebbal et al., 2018). Under transplanting, age of seedling, spacing and number of seedlings are the major yield limiting factors and optimization of these factors allows the plants to utilize the maximum resources, leading to increased productivity. Altering the above parameters may not influence the cost of production, but they contribute to higher return through yield enhancement.

Tillering is the critical yield contributing character, which mainly depends on the age of seedlings at the time of transplanting (Pasuquin et al., 2008). Beyond the optimum age of seedlings, the crop cannot attain its full growth and yield potential. Plant density is another essential factor determined by crop spacing and the number of seedlings per hill. They largely influence the interception of solar radiation, photosynthesis rate, water, nutrient uptake, and other physiological phenomena (Imran et al., 2015). 
If plant density exceeds an optimum, competition among plants for above and below ground resources becomes severe (Bayala et al., 2002). Keeping in view the above important points, the present research was conducted to find the optimum age of seedlings, spacing, and number of seedlings per hill to get higher productivity and profitability of finger millet under transplanted conditions.

\section{MATERIAL AND METHODS}

During the Kharif season of 2019 (July to November), the field experiment was carried out in field No. 37F at Eastern block farm, Department of Agronomy, Tamil Nadu Agricultural University, Coimbatore. The research farm is located in the Western Agro Climatic Zone of Tamil Nadu at $11^{\circ} 01^{\prime} \mathrm{N}$ latitude, $76^{\circ} 93^{\prime} \mathrm{E}$ longitude, and an altitude of $427 \mathrm{~m}$ above MSL. The experimental soil was sandy clay loam in texture and was slightly alkaline ( $\mathrm{pH}$-7.99) with low soluble salts (EC-1.2 dS $\left.\mathrm{m}^{-1}\right)$. Irrigation water used for the experiment was slightly alkaline $(\mathrm{pH}-8)$ with high soluble salts (EC$5.7 \mathrm{dS} \mathrm{m}^{-1}$ ).

The experiment was laid out in a split-plot design with three replications. The main plot consisted of three seedling ages viz., $14\left(\mathrm{M}_{1}\right), 17\left(\mathrm{M}_{2}\right)$ and 20 $\left(\mathrm{M}_{3}\right)$ days old seedlings and subplot consisted of four planting patterns viz., rectangular planting (30 $\mathrm{cm} \times 10 \mathrm{~cm}$ spacing) with one seedling per hill $\left(\mathrm{S}_{1}\right)$, square planting $(25 \mathrm{~cm} \times 25 \mathrm{~cm}$ spacing) with one seedling per hill $\left(\mathrm{S}_{2}\right)$, rectangular planting $(30 \mathrm{~cm} \times$ $10 \mathrm{~cm}$ spacing) with two seedlings per hill $\left(\mathrm{S}_{3}\right)$ and square planting ( $25 \mathrm{~cm} \times 25 \mathrm{~cm}$ spacing) with two seedlings per hill $\left(\mathrm{S}_{4}\right)$.

Healthy seeds of finger millet variety CO 15 were selected for sowing. Seeds were sown in raised nursery beds with a seed rate of $7.5 \mathrm{~kg} \mathrm{ha}^{-1}$ and covered with vermicompost. For transplanting seedlings of different ages, nursery sowing was carried out on three different days with two days intervals. In main field preparation, FYM @ 12.5 t ha $^{-1}$ was uniformly applied at last ploughing and at the time of transplanting, TNAU MN mixture @12.5 kg ha-1 blended with Azospirillum and Phosphobacteria each @ 2 kg ha-1 were applied. The recommended fertilizer rate for finger millet is $60: 30: 30 \mathrm{~kg} \mathrm{ha}^{-1}$ of $\mathrm{N}, \mathrm{P}_{2} \mathrm{O}_{5}$, and $\mathrm{K}_{2} \mathrm{O}$. For each treatment plot, a half dose of $\mathrm{N}$, full dose of $\mathrm{P}_{2} \mathrm{O}_{5}$, and $\mathrm{K}_{2} \mathrm{O}$ were applied as basal and the remaining half dose of $\mathrm{N}$ was topdressed at 30 DAT. Seedlings aged 14, 17 and 20 days were separately uprooted from the respective nursery beds and transplanted in the main field. All the treatment factors were carefully considered and incorporated as per the requirement at the time of transplanting. All the management practices followed above were based on CPG, 2019. Grain yield and straw yield were calculated based on the yields obtained from the whole net plot area of the treatment plot.

The labor requirement for different field operations in each treatment was recorded separately and the labor productivity was worked out using the following formula (Pratten, 1976).

$$
\begin{aligned}
& \text { Labour productivity } \\
& \left(₹ \text { man day }{ }^{-1}\right)
\end{aligned}=\frac{\text { Output }(₹ \text { ha-1 })}{\text { Labour input }(\text { Man days ha-1) }}
$$

The cost of cultivation was worked out as per the input price followed in TNAU. The worked-out cost of ₹ 32,678 ha $^{-1}$ was commonly considered irrespective of different treatments and added with individual treatment costs to get the total cost of cultivation. The sale price of grain yield was calculated based on the MSP given by the Government of India (MAFW, 2019), and income from straw yield was worked out based on current market prices for outputs followed in TNAU.

\section{RESULTS AND DISCUSSION}

The results on grain yield, straw yield, labor productivity, and finger millet economics as influenced by seedling age and planting pattern are discussed below. The data on grain and straw yields were analyzed statistically and presented in Table 1 and Figure 1, whereas labour productivity and economics were not analyzed statistically but numerically worked out and presented in Table 2 and Figure 2, respectively.

Table 1. Influence of seedling age and planting pattern on grain yield $\left(\mathrm{kg} \mathrm{ha}^{-1}\right)$ and straw yield $\left(\mathrm{kg} \mathrm{ha}^{-1}\right)$ of finger millet

\begin{tabular}{lcccccccc}
\hline \multirow{2}{*}{ Treatments } & \multicolumn{3}{c}{ Grain yield $\left(\mathbf{k g ~ h a}^{-\mathbf{1}}\right)$} & \multicolumn{4}{c}{ Straw yield $\left(\mathbf{k g ~ h a} \mathbf{~}^{-1}\right)$} \\
\cline { 2 - 9 } & $\mathbf{M}_{\mathbf{1}}$ & $\mathbf{M}_{\mathbf{2}}$ & $\mathbf{M}_{\mathbf{3}}$ & $\mathbf{M e a n}$ & $\mathbf{M}_{\mathbf{1}}$ & $\mathbf{M}_{\mathbf{2}}$ & $\mathbf{M}_{\mathbf{3}}$ & $\mathbf{M e a n}$ \\
\hline $\mathrm{S}_{1}$ & 3281 & 3560 & 3625 & 3489 & 8112 & 8510 & 8778 & 8467 \\
$\mathrm{~S}_{2}$ & 3202 & 3338 & 3491 & 3344 & 7510 & 7841 & 7981 & 7777 \\
$\mathrm{~S}_{3}$ & 3658 & 3923 & 3980 & 3853 & 8413 & 8622 & 8804 & 8613 \\
$\mathrm{~S}_{4}$ & 3432 & 3753 & 3895 & 3693 & 7919 & 7890 & 8144 & 7984 \\
Mean & 3393 & 3644 & 3748 & 3595 & 7989 & 8216 & 8427 & 8210 \\
Factors & $\mathrm{M}$ & $\mathrm{S}$ & $\mathrm{M} \times \mathrm{S}$ & $\mathrm{S} \times \mathrm{M}$ & $\mathrm{M}$ & $\mathrm{S}$ & $\mathrm{M} \times \mathrm{S}$ & $\mathrm{S} \times \mathrm{M}$ \\
$\mathrm{SEd}$ & 77.0 & 77.4 & 139.4 & 134.1 & 56.5 & 73.4 & 123.8 & 127.2 \\
$\mathrm{CD}(\mathrm{P}=0.05)$ & 213.8 & 162.7 & $\mathrm{NS}$ & $\mathrm{NS}$ & 156.9 & 154.3 & $\mathrm{NS}$ & $\mathrm{NS}$ \\
\hline
\end{tabular}

Main plot: Seedling age

$M_{1}$ : Transplanting of 14 days old seedlings

$\mathrm{M}_{2}$ : Transplanting of 17 days old seedlings

$\mathrm{M}_{3}$ : Transplanting of 20 days old seedlings

\section{Sub plot: Planting pattern}

$\mathrm{S}_{1}$ : Rectangular planting $(30 \times 10 \mathrm{~cm})$ with one seedling per hill

$\mathrm{S}_{2}$ : Square planting $(25 \times 25 \mathrm{~cm})$ with one seedling per hill

$\mathrm{S}_{3}$ : Rectangular planting $(30 \times 10 \mathrm{~cm})$ with two seedlings per hill

$\mathrm{S}_{4}$ : Square planting $(25 \times 25 \mathrm{~cm})$ with two seedlings per hill 


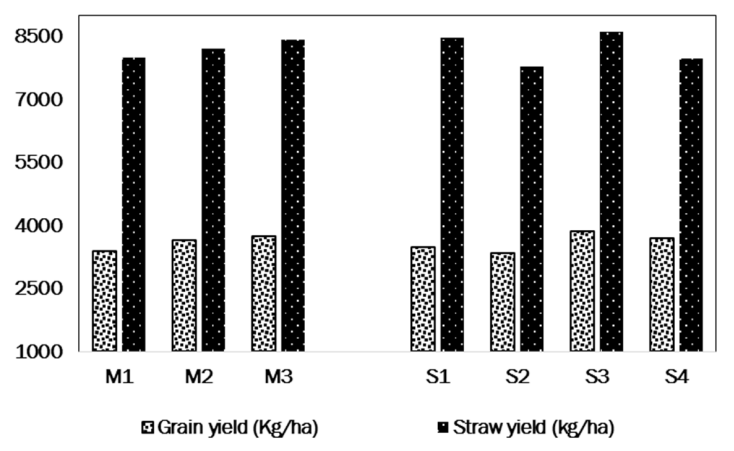

Fig 1. Influence of seedling age and planting pattern on grain yield $\left(\mathrm{kg} \mathrm{ha}^{-1}\right)$ and straw yield ( $\left.\mathrm{kg} \mathrm{ha}^{-1}\right)$ of finger millet

\section{Grain yield and straw yield as influenced by seedling age and planting pattern}

In transplanting, seedling age and planting pattern had a significant impact on grain and straw yields of finger millet, however, the interaction effect was non-significant.

Transplanting 20 days-aged seedlings $\left(\mathrm{M}_{3}\right)$ recorded a higher grain yield of $3748 \mathrm{~kg} \mathrm{ha}^{-1}$, followed by 17 days old seedlings $\left(\mathrm{M}_{2}\right)$. Better root establishment at transplanting in 20 days older seedlings tend to faster establishment and growth, which might increase the yield compared to younger seedlings. Comparatively, a lower grain yield of 3393 $\mathrm{kg} \mathrm{ha}^{-1}$ was obtained from 14 days $\left(\mathrm{M}_{1}\right)$ seedlings. Grain yield decreased with decreasing age of seedlings, as reported by Alam et al. (2002), Khatun et al. (2002), and Sarker et al. (2013). Among different planting patterns, rectangular planting $(30 \mathrm{~cm} \times 10 \mathrm{~cm})$ with two seedlings per hill $\left(\mathrm{S}_{3}\right)$ recorded a higher grain yield of $3853 \mathrm{~kg} \mathrm{ha}^{-1}$, which was comparable with square planting $(25 \mathrm{~cm} \times 25$ $\mathrm{cm}$ ) with two seedlings per hill $\left(\mathrm{S}_{4}\right)$. More tillers per unit area in rectangular planting favored higher grain yield, whereas increased yield attributes per hill in square planting encouraged the grain yield. Square planting $(25 \mathrm{~cm} \times 25 \mathrm{~cm}$ ) with a single seedling per hill $\left(\mathrm{S}_{2}\right)$ observed a lower grain yield of $3344 \mathrm{~kg} \mathrm{ha}^{-1}$, which was statistically comparable with rectangular planting $(30 \mathrm{~cm} \times 10 \mathrm{~cm})$ with a single seedling per hill $\left(S_{1}\right)$. This was mainly due to the fewer tillers per unit area than other planting patterns. Thakur et al. (2010) reported that beyond optimum plant density, wider spacing does not give higher grain yield on an area basis than closer spacing. According to Paul et al. (2002) and Faruk et al. (2009), two seedlings per hill produced higher grain yield compared to a single seedling per hill. The results agreed with the findings of Rasool et al. (2012) and Vijayalaxmi et al. (2016).

Table 2. Influence of seedling age and planting pattern on labor productivity (₹ man days $\left.{ }^{-1}\right)$ of finger millet

\begin{tabular}{|c|c|c|c|c|c|c|c|c|}
\hline \multirow{2}{*}{\multicolumn{2}{|c|}{ Treatments }} & \multicolumn{4}{|c|}{ Labour input (man days) } & \multirow{2}{*}{$\begin{array}{l}\text { Total labor } \\
\text { input (man } \\
\text { days) }\end{array}$} & \multirow{2}{*}{$\begin{array}{l}\text { Gross return } \\
\left(₹ h^{-1}\right)\end{array}$} & \multirow{2}{*}{$\begin{array}{l}\text { Labor productivit } \\
\left(₹ \text { man days }{ }^{-1} \text { ) }\right.\end{array}$} \\
\hline & & Transplanting & $\begin{array}{l}\text { Gap } \\
\text { filling }\end{array}$ & Weeding & Harvesting & & & \\
\hline \multirow{4}{*}{$M_{1}$} & $\mathbf{S}_{1}$ & 27 & 3 & 23 & 22 & 75 & 107,408 & 1432 \\
\hline & $\mathbf{S}_{2}$ & 31 & 2 & 20 & 19 & 72 & 104,618 & 1453 \\
\hline & $\mathbf{S}_{3}$ & 26 & 3 & 23 & 25 & 77 & 119,434 & 1551 \\
\hline & $\mathbf{S}_{4}$ & 30 & 2 & 20 & 20 & 72 & 112,068 & 1556 \\
\hline \multirow{4}{*}{$\mathbf{M}_{2}$} & $\mathbf{S}_{1}$ & 22 & 2 & 23 & 22 & 69 & 116,395 & 1687 \\
\hline & $\mathbf{S}_{2}$ & 29 & 1 & 20 & 19 & 69 & 109,068 & 1581 \\
\hline & $\mathbf{S}_{3}$ & 20 & 2 & 23 & 25 & 70 & 127,886 & 1827 \\
\hline & $\mathbf{S}_{4}$ & 29 & 1 & 20 & 20 & 70 & 122,165 & 1745 \\
\hline \multirow{4}{*}{$M_{3}$} & $\mathbf{S}_{1}$ & 22 & 2 & 23 & 22 & 69 & 118,577 & 1719 \\
\hline & $\mathbf{S}_{2}$ & 25 & 1 & 20 & 19 & 65 & 113,957 & 1753 \\
\hline & $\mathbf{S}_{3}$ & 18 & 2 & 23 & 25 & 68 & 129,772 & 1908 \\
\hline & $\mathbf{S}_{4}$ & 27 & 1 & 20 & 20 & 68 & 126,765 & 1864 \\
\hline
\end{tabular}

* Labour charges ₹ 360 man day $^{-1}$ for all the above mentioned operations (one man day - 8 hours)

\section{Main plot: Seedling age}

$\mathrm{M}_{1}$ : Transplanting of 14 days old seedlings

$\mathrm{M}_{2}$ : Transplanting of 17 days old seedlings

$\mathrm{M}_{3}$ : Transplanting of 20 days old seedlings

\section{Sub plot: Planting pattern}

$\mathrm{S}_{1}$ : Rectangular planting $(30 \times 10 \mathrm{~cm})$ with one seedling per hill

$\mathrm{S}_{2}$ : Square planting $(25 \times 25 \mathrm{~cm})$ with one seedling per hill

$\mathrm{S}_{3}$ : Rectangular planting $(30 \times 10 \mathrm{~cm})$ with two seedlings per hill

$\mathrm{S}_{4}$ : Square planting $(25 \times 25 \mathrm{~cm})$ with two seedlings per hill 


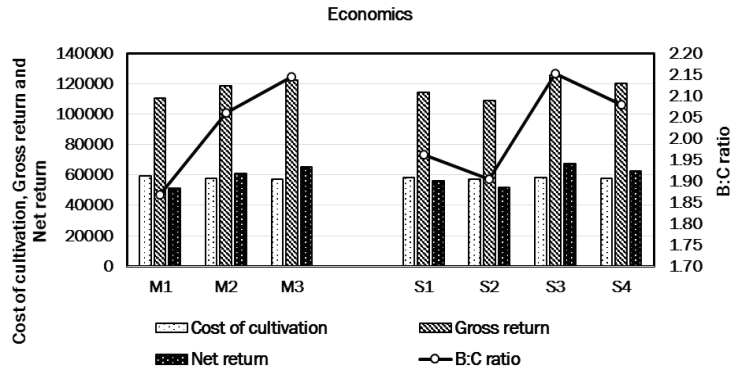

Fig 2. Influence of seedling age and planting pattern on economics of finger millet

A higher straw yield of $8427 \mathrm{~kg} \mathrm{ha}^{-1}$ was obtained from transplanting of 20 days old seedlings $\left(M_{3}\right)$ followed by 17 days old seedlings $\left(M_{2}\right)$. Seedlings aged 20 days exhibited better growth and development throughout the crop period and resulted in higher straw yield than younger seedlings. The results are in agreement with the findings of El-Khoby and Shahein (2016). A significantly lower straw yield of $7989 \mathrm{~kg} \mathrm{ha}^{-1}$ was recorded with 14 days seedlings $\left(\mathrm{M}_{1}\right)$. Rectangular planting $(30 \mathrm{~cm} \times 10 \mathrm{~cm})$ with two seedlings per hill $\left(\mathrm{S}_{3}\right)$ recorded a higher straw yield of $8613 \mathrm{~kg} \mathrm{ha}^{-1}$. However, the treatment was statistically comparable with rectangular planting $(30 \mathrm{~cm} \times 10 \mathrm{~cm})$ with a single seedling per hill $\left(\mathrm{S}_{1}\right)$. Higher plant population in rectangular planting led to higher straw yield than square planting, which showed a lower plant population. The results conform the findings of Hebbal et al. (2018) and Korir et al. (2018), who reported that closer spacing produced a higher yield of straw than wider spacing. A significantly lower straw yield of $7777 \mathrm{~kg} \mathrm{ha}^{-1}$ was recorded under square planting $(25 \mathrm{~cm} \times 25 \mathrm{~cm})$ with a single seedling per hill $\left(\mathrm{S}_{2}\right)$. According to Faruk et al. (2009), Bhowmik et al. (2012), and Vijayalaxmi et al. (2016), single seedling per hill produced lower straw yield than more number of seedlings per hill.

\section{Labour productivity as influenced by seedling age and planting pattern}

Labor productivity is a measure to estimate the labor input, which would convert into the output in terms of economics. Seedlings of 20 days old transplanted under rectangular planting $(30 \mathrm{~cm} \times$ $10 \mathrm{~cm}$ ) with two seedlings per hill $\left(\mathrm{M}_{3} \mathrm{~S}_{3}\right)$ recorded higher labor productivity ( $₹ 1908$ man day $^{-1}$ ). Higher gross return and the added advantage of lower labor requirement indicated the efficient conversion of input (labour) into output (yield), which might be the reason for higher labour productivity in older seedlings with rectangular planting with two seedlings per hill. The findings of Rakotomalala (1997) revealed that $\mathrm{SCl}$ in rice required more labours for transplanting than conventional planting. Comparatively, lower labour productivity (₹ 1432 man day $^{-1}$ ) was obtained with 14 days old seedlings transplanted under rectangular planting $(30 \mathrm{~cm} \times$
$10 \mathrm{~cm}$ ) with a single seedling per hill $\left(\mathrm{M}_{1} \mathrm{~S}_{1}\right)$. Smaller seedling sizes with a higher mortality rate in younger seedlings (14 days old) tend to have higher labor requirements for transplanting and gap filling. At the same time, younger seedlings under rectangular planting with a single seedling per hill produced lesser grain yield (Kewat et al., 2002), reducing labor productivity.

\section{Economics as influenced by seedling age and planting pattern}

The higher cost of cultivation ( $₹ 60,398 \mathrm{ha}^{-1}$ ) was recorded with transplanting of younger seedlings of 14 days old under rectangular planting $(30 \mathrm{~cm} \times$ $10 \mathrm{~cm}$ ) with two seedlings per hill $\left(\mathrm{M}_{1} \mathrm{~S}_{3}\right)$. Younger seedlings of 14 days old required more labor input for transplanting and gap filling. Seed cost for gap filling was also higher in younger seedlings, increasing the cost. Similarly, rectangular planting with two seedlings per hill required more seed and labour due to higher plant population per unit area than square planting and single seedling per hill. Whereas the lower cultivation cost (₹ 56,078 ha-1) was recorded with the age of 20 days old seedlings transplanted under square planting $(25 \mathrm{~cm} \times 25$ $\mathrm{cm}$ ) with a single seedling per hill $\left(\mathrm{M}_{3} \mathrm{~S}_{2}\right)$. Lengthier seedlings in 20 days old consumed less labour time for transplanting and quicker establishment and plant stand took minimum seed and labor for gap filling. This might have reduced the cost of cultivation in older seedlings. Similar results were recorded by Damodaran et al. (2012) and Hebbal et al. (2018), who reported that a higher cost of cultivation was recorded under closer spacing. Similarly, transplanting single seedlings per hill recorded a lower cost of cultivation than two seedlings per hill (Devi et al., 2019).

Transplanting of 20 days old seedlings under rectangular planting $(30 \mathrm{~cm} \times 10 \mathrm{~cm})$ with two seedlings per hill $\left(\mathrm{M}_{3} \mathrm{~S}_{3}\right)$ recorded a higher gross return of ₹ 129,772 ha $^{-1}$ compared to other treatments. Seedlings aged 20 days transplanted under rectangular planting with two seedlings per hill attributed better plant establishment and higher population. This might have facilitated increased grain yield and straw yield and resulted in higher gross return. Transplanting of 14 days old seedlings under square planting $(25 \mathrm{~cm} \times 25 \mathrm{~cm})$ with a single seedling per hill $\left(\mathrm{M}_{1} \mathrm{~S}_{2}\right)$ recorded a numerically lower gross return of ₹ $104,618 \mathrm{ha}^{-1}$. Poor establishment and growth in younger seedlings coupled with lower plant population in square planting with a single seedling per hill might have reduced gross return by lowering the yields. The results are following the finding of Ram et al. (2014) and Hebbal et al. (2018).

A comparatively higher net return of ₹ 72,614 ha $^{-1}$ was acquired with 20 days old seedlings under 
rectangular planting $(30 \mathrm{~cm} \times 10 \mathrm{~cm})$ with two seedlings per hill $\left(\mathrm{M}_{3} \mathrm{~S}_{3}\right)$. Higher gross return and the lower cost of cultivation resulted in a higher net return. Similar findings were reported by Ram et al. (2014) and Hebbal et al. (2018), who found that a spacing of $30 \times 10 \mathrm{~cm}$ recorded a higher net return compared to wider spacings. Transplanting of two seedlings per hill recorded a higher net return compared to a single seedling per hill as reported by Damodaran et al. (2012). Comparatively lower net return of ₹ 46,020 ha ${ }^{-1}$ was recorded with 14 days old seedlings under square planting $(25 \mathrm{~cm} \times 25$ $\mathrm{cm})$ with a single seedling per hill $\left(\mathrm{M}_{1} \mathrm{~S}_{2}\right)$.

The calculated value on benefit-cost ratio was higher (2.27) in transplanting of 20 days old seedlings under rectangular planting $(30 \mathrm{~cm} \times 10$ $\mathrm{cm})$ with two seedlings per hill $\left(\mathrm{M}_{3} \mathrm{~S}_{3}\right)$. According to Ram et al. (2014) and Hebbal et al. (2018), closer spacing of $30 \mathrm{~cm} \times 10 \mathrm{~cm}$ recorded a higher $\mathrm{B}: \mathrm{C}$ ratio. Whereas, younger seedlings of 14 days old transplanted under square planting $(25 \mathrm{~cm} \times 25$ $\mathrm{cm})$ with a single seedling per hill $\left(\mathrm{M}_{1} \mathrm{~S}_{2}\right)$ recorded a comparatively lower benefit-cost ratio of 1.79 .

\section{CONCLUSION}

It is evident from the above results, that transplanting of 20 days old seedlings under rectangular planting $(30 \mathrm{~cm} \times 10 \mathrm{~cm})$ with two seedlings per hill was an economically viable option to achieve higher yield and profit in transplanted finger millet under Western Agro Climatic zone of Tamil Nadu.

\section{Ethics statement}

This article does not contain any studies with human participants or animals performed by any of the authors.

\section{Consent for publication}

All the authors agreed to publish the content.

\section{Competing Interests}

The authors declare no conflict of interest in publication of this content

\section{REFERENCES}

AICSMIP (All India Co-ordinated Small Millets Improvement Project) Annual Report 2014. Report on compendium of released varieties in small millets. ICAR. GKVK, Bangalore.

Alam, M., Ahmed, M., Alam, M., Haque, M. and M. Hossin. 2002. Performance of seedling ages and seedling raising techniques on yield and yield components of transplant Aman rice. Pak. J. Biol. Sci., 5(11): 1214-1216.

Bayala, J., Teklehaimanot, Z. and S. Ouedraogo. 2002. Millet production under pruned tree crowns in a parkland system in Burkina Faso. Agrofor. Syst., 54(3): 203-214.
Bhowmik, S., Sarkar, M. and F. Zaman. 2012. Effect of spacing and number of seedlings per hill on the performance of aus rice cv. NERICA 1 under dry direct seeded rice (DDSR) system of cultivation. $J$. Bangladesh Agril. Univ., 10(2): 191-196.

Chamoli, V., Badoni, A., Bahuguna, N. and N. Joshi. 2018. Finger millet (Eluesine coracana) Nutritional status, health benefits and processing status-A review. SP5: 80-83

Chappalwar, V.M., Peter, D., Bobde, H. and S. M. John. 2013. Quality characteristics of cookies prepared from oats and finger millet based composite flour. Eng. Sci. Technol. 3 (4): 677-683.

CPG. 2019. Crop Production Guide. Department of Agriculture, Govt. of Tamil Nadu, Chennai and Tamil Nadu Agricultural University, Coimbatore.

Damodaran, V., Saren, B., Ravisankar, N. and N. Bommayasamy. 2012. Influence of time of planting, spacing, seedling number and nitrogen management practices on productivity, profitability and energetics of rice (Oryza sativa) in island ecosystem. Madras Agric. J., 99(7-9): 538-544.

Devi, K. N., Narayan, G., Singh, K. K., Devi, M. A., Athokpam, H. S. and A. D. Singh. 2019. Effect of Age and Number of Seedling per Hill on Growth and Yield of Black Scented Rice (Oryza sativa L.) Variety 'Chakhao Poireiton'under Manipur Condition.Int. J. Curr. Microbiol. Appl. Sci., 8(7): 1738-1745.

El-Khoby, M. and A. M. Shahein. 2016. Effect of irrigation management and seedling age on the productivity and quality of two rice varieties using system of rice intensification (SRI). J. Sus. Agric. Sci., 42(3): 288-299

Faruk, M., Rahman, M. and M. Hasan. 2009. Effect of seedling age and number of seedling per hill on the yield and yield contributing characters of BRRI Dhan 33. Int. J. Sustain. 4 (1): 58-61.

Hebbal, N., Ramachandrappa, B. and M. Thimmegouda. 2018. Yield and economics of finger millet with establishment methods under different planting geometry and nutrient source. Indian J. Dryland Agric. Res. \& Dev. 33 (1): 54-58.

Imran, A. A. K, Inamullah, F. A. S., Naeem, L. Z. M. and M. N. Khan. 2015. Phenological Traits of Rice as Influenced by Seedling Age and Number of Seedling Per Hill under Temperate Region. Journal of Biology, Agriculture and Healthcare 5(3): 145-149.

Khatun, A., Mollah, M., Rashid, I., Islam, M. and A. Khan. 2002. Seasonal effect of seedling age on the yield of rice. Pak. J. Biol. Sci., 5 (1): 40-42.

Kewat, M., Agrawal, S., Agrawal, K. and R. Sharma. 2002. Effect of divergent plant spacings and age of seedlings on yield and economics of hybrid rice (Oryza sativa). Indian J. Agron., 47 (3): 367-371.

Korir, A., Kamau, P. and D. Mushimiyimana. 2018. Effect of fertilization and spacing on growth and grain yields of finger millet (Eleusine Coracana L.) in Ainamoi, Kericho County, Kenya. Int. J. Adv. Res. Publ., 2(10): 34-44.

MAFW (Ministry of Agriculture and Farmers Welfare) 2019, Minumum Support Prise (MSP), Govt. 
of India, https://pib.gov.in/PressReleasePage. aspx?PRID=1576844

Pasuquin, E., Lafarge, T. and B. Tubana. 2008. Transplanting young seedlings in irrigated rice fields: early and high tiller production enhanced grain yield. Field Crops Res., 105 (1\&2): 141-155.

Paul, S., Sarkar, M. and M. Ahmed. 2002. Effect of row arrangement and tiller separation on the yield and yield components of transplant aman rice. $J$. Agron., 1 (1): 9-11.

Pratten, C.F. 1976. Labour productivity differentials within international companies. Vol. 50: Cambridge University Press.

Rakotomalala, H. W. 1997. Comparison entre la Rizicullture Traditionnelle et le Systeme de Riziculture Intensive dans La Region de Ranomafana. Me'moire fin d'e'tudes, Thesis, Department of Agriculture, University of Antananarivo, Antananarivo.

Ram, H., Singh, J., Bohra, J., Singh, R. K. and J. Sutaliya. 2014. Effect of seedlings age and plant spacing on growth, yield, nutrient uptake and economics of rice (Oryza sativa) genotypes under system of rice intensification. Indian J. Agron. 59(2): 256-260.

Rasool, F., Habib, R. and M. Bhat. 2012. Evaluation of plant spacing and seedlings per hill on rice (Oryza sativa L.) productivity under temperate conditions. Pak. J. Biol. Sci., 49 (2): 169-172.

Sarker, T., Hossain, M., Salam, M. and M. Rabbani. 2013. Effect of seedling age and method of transplanting on the yield of Aman rice. Progress. Agric. 24(1\&2): 9-16.

Thakur, A., Rath, S., Roychowdhury, S. and N. Uphoff. 2010. Comparative performance of rice with system of rice intensification (SRI) and conventional management using different plant spacings. J. Agron. Crop Sci. 196(2): 146-159.

Vijayalaxmi, G., Sreenivas, G., Rani, P. L. and A. Madhavi. 2016. Effect of plant densities and age of seedlings on growth and yield parameters of kharif rice. Int. J. Environ. Sci. Technol. 5(3): 1153-1162. 